\title{
Processing engineering of large composites structures using low-pressure vacuum infusion
}

Rusnáková, Soňa ${ }^{1)}$, doc. Ing. Ph.D. Žaludek, Milan ${ }^{1)}$, Ing. Ph.D., Bakošová, Dana ${ }^{2)}$, Ing, Ph.D.,

${ }^{1)}$ Department of Production Engineering, FT UTB ve Zlíně

${ }^{2)}$ Department of Industrial Technologies and Materials, FPT in Púchov, TnUAD

Composite materials, such as fibre reinforced plastics and sandwich panels, have considerable potential for use in the next generation of transport structures. They are lightweight, durable, and readily moulded to shape. However, there are also additional complexities associated with the use of composites, particularly in terms of design and manufacture. These complexities, together with issues of cost, are currently limiting their adoption by the transport sectors. The selection of the manufacturing process for a composite component will normally depend upon the nature of part and the required production volumes. We try to present vacuum assisted resin infusion process, suitable for low-medium production volumes (less than 500 parts per year). Vacuum infusion is well suited to large parts (greater than $1 \mathrm{~m}$ ) with intermediate fibre content (less than $35 \%$ by volume). As a reference product was selected overhead - side panel of train cabin designed like a sandwich construction with suitable foam or honeycomb core. Our experimental results described vacuum infusion process like actual variant to produce designed products to transport industry.

Keywords: vacuum infusion, matrix, sandwich construction.

\section{References}

[1] KANG, M.K., LEE, W.I., HAHN, H.T.: Analysis of Vacuum Bag Resin Transfer Molding process, Composites, A 32, 2001, p. 1553-1560.

[2] HAMMAMI A.: Effect of reinforcement structure on compaction behavior in the vacuum infusion process, Polym Compos., 2001, 22 p. 337-48.

[3] ŠUBA O., SYKOROVA L., MALACHOVA M., SAMEK D.: Modelling of Transient Thermal Stress in Layered Walls, Manufacturing Technology X, Vol. 10, p.16-19, ISSN 1213-2489, 2010.

[4] MULLER M., NAPRSTKOVA N.: Possibilities and limits of adhesive layer thickness optical evaluation, Manufacturing Technology X, Vol. 10, p.45-49-19, ISSN 1213-2489, 2010.

[5] HSIAO, K-T., MATHUR,R., ADVANI, S. G., GILlESPIE J. W, B. Jr., FINK,K.: A closed form solution for flow during the vacuum assisted resin transfer molding process, Journal of Manufacturing Science and Engineering, 2000, 122, p. 463-475.

[6] FEILER, M,. ISCHTSCHUK, L.: Vacuum assisted resin infusion (VARI): on the way to serial production. 24th International SAMPE Europe Conference, 2003, Paris, France, p. 683-691

[7] ANDERSSON, H. M, LUNDSTROM, T.S., B.R. GEBART, R. LANGSTROM. Flow enhancing layers in the vacuum infusion process, Polymer composites, 2002, 23, №5, p. 895-901.

[8] HOEBERGEN, A., HOLMBERG, J.: Vacuum infusion, ASM Handbook, 21, Composites, Materials Park (OH), 2001, p. 501-515.

[9] CORREIA, N. C.: Analysis of the vacuum infusion moulding process, PhD thesis, 2004, University of Nottingham.

Paper number: M201219

Manuscript of the paper recieved in 2011-12-18. The reviewers of this paper: Assoc. Prof. Dana Bolibruchova, MSc, PhD. and Prof.Iva Nova, MSc., Ph.D. 